\title{
Go and separate: a strategic intervention material (SIM) in improving the academic performance of grade 6 science pupils
}

Ir y separar: un material de intervención estratégico (MIE) para mejorar el rendimiento escolar de los alumnos de ciencias de $6^{\text {to }}$ grado

Ir e separar: um material de intervenção estratégica (MIE) para melhorar o desempenho acadêmico de alunos de ciência da $6^{\mathrm{a}}$ série

Jocoh P. Romero, PhD (C)

jocoh.romero@deped.gov.ph

Rizal Central Elementary School, Kapatagan, Digos City, Davao del Sur https://orcid.org/0000-0002-0069-1265

\begin{abstract}
This study dealt on how I improved the academic performance of my learners on the topic of separating mixtures at Rizal Central Elementary School, Kapatagan, Digos City for the school year 2020-2021. Guide cards, activity cards, assessment cards, enrichment cards and reference cards comprised the Strategic Intervention Material (SIM) entitled "Go and Separate" which was used as a form of remediation. The material covers one of the least-learned competencies in Science VI, Quarter I which is "enumerate techniques in separating mixtures such as decantation, evaporation, filtering, sieving, distillation, and using magnet" and for this study, decantation and evaporation were focused. The data collection was performed using pretest, posttest, and perception survey questionnaire. It was analyzed quantitatively and qualitatively. It was concluded that based on the outcomes of the study, the use of Strategic Intervention Material (SIM) has contributed meaningfully to the academic performance of the learners. It was also perceived that the participants exhibited enthusiasm and enjoyed the use of Strategic Intervention Material (SIM) through their positive responses based on their answers on perception survey questionnaire.
\end{abstract}

Keywords: academic performance, separating mixtures, strategic intervention material, remediation, perception survey questionnaire

\section{RESUMEN}

Este estudio trató sobre cómo mejoré el rendimiento académico de mis alumnos en el tema de separar mezclas en la Escuela Primaria Rizal Central, Kapatagan, Ciudad de Digos para el año escolar 2020-2021. Las tarjetas de guía, las tarjetas de actividades, las tarjetas de evaluación, las tarjetas de enriquecimiento y las tarjetas de referencia comprendían el Material de intervención estratégica (SIM) titulado "Ir y separarse" que se utilizó como una forma de remediación. El material cubre una de las competencias menos aprendidas en Ciencia VI, Trimestre I que es "enumerar técnicas en la separación de mezclas como decantación, evaporación, filtrado, tamizado, destilación y uso de imán" y para este estudio, se enfocaron la decantación y evaporación. La recolección de datos se realizó mediante cuestionario de encuesta de percepción, preprueba y posprueba. Se analizó cuantitativa y cualitativamente. Se concluyó que, con base en los resultados del estudio, el uso de Material de Intervención Estratégica (SIM) ha contribuido de manera significativa al rendimiento académico de los alumnos. También se percibió que los participantes mostraron entusiasmo y disfrutaron del uso del Material de Intervención Estratégica (SIM) a través de sus respuestas positivas basadas en sus respuestas en el cuestionario de la encuesta de percepción.

Palabras clave: rendimiento académico, mezclas de separación, material de intervención estratégica, remediación, cuestionario de encuesta de percepción

\section{RESUMO}

Este estudo tratou de como melhorei o desempenho acadêmico dos meus alunos no tópico de separação de misturas na Rizal Central Elementary School, Kapatagan, Digos City para o ano letivo de 2020-2021. Cartões-guia, cartões de atividades, cartões de avaliação, cartões de enriquecimento e cartões de referência compunham o Material de Intervenção Estratégica (SIM) intitulado "Vá e Separe" que foi utilizado como forma de remediação. O material cobre uma das competências menos aprendidas na Ciência VI, Trimestre I, que é "enumerar técnicas na separação de misturas, como decantação, evaporação, filtragem, peneiramento, destilação e uso de ímã" e para este estudo, decantação e evaporação foram focadas . A coleta de dados foi realizada por meio de pré-teste, pós-teste e questionário 
de pesquisa de percepção. Foi analisado quantitativa e qualitativamente. Concluiu-se que, com base nos resultados do estudo, a utilização do Material de Intervenção Estratégica (SIM) tem contribuído de forma significativa para o desempenho acadêmico dos alunos. Percebeu-se também que os participantes demonstraram entusiasmo e gostaram da utilização do Material de Intervenção Estratégica (SIM) por meio de suas respostas positivas a partir de suas respostas no questionário da pesquisa de percepção.

Palavras-chave: desempenho acadêmico, separando misturas, material de intervenção estratégica, remediação, questionário de pesquisa de percepção

\section{INTRODUCTION}

Learning how mixtures is separated in a science class requires mastery of the subject matter itself and the teacher being resourceful in delivering his or her lesson. Being knowledgeable on the topics that you are going to teach is a pre-requisite skill in targeting your goal which is to make your leaners apply what they have learned in the real-life setting. It is always necessary to provide a fun and exciting learning experience that will cater all the learners regardless of their academic standing. You must be certain in identifying all ways and means to help your learners master all the competencies stated in the $\mathrm{K}$ to 12 Curriculum Guide now Most Essential Learning Competencies (MELCs). As a facilitator of learning, I always ready myself before I enter my class. I made it sure that my daily lesson logs and instructional materials are set before time.

The academic performance of my Grade VI-Bonifacio learners for the School Year 2017-2018, 2018-2019 and 2019-2020 for the First Grading Examination was remarkably low despite my effort in giving them a meaningful and competent teaching-learning experience. The average Mean Percentage Score (MPS) of this section for the last three years is $69.40 \%$ against the target set by the Education Supervisor in Science which is $75 \%$ to $78 \%$. Furthermore, the graph derived from Pareto analysis reveals that among the three competencies indicated in the table of specification of the crafted summative tests administered to the learners for the said school years, enumerate techniques in separating mixtures such as decantation, evaporation, filtering, sieving, distillation and using magnet was highlighted as most frequent reason why the MPS reported is relatively poor. When I took a closer look on these test items on the summative tests administered to the learners, I found out that most difficult separating technique encountered by my learners are decantation and evaporation.

It was very alarming to note that the performance of these learners does not meet the standard set in the subject area. The performance of these learners was a contributing factor to the performance of the teachers and the school.

Being in the Department of Education for five years now, I understood that there is always a room to improve myself and to be certain with what kind of approach that I will use to keep my learners on track as the teaching-learning continues. For some learners, Science learning is too way boring and burdensome, and they display lack of interest in it. I have helped my learners acquire mastery on the topic of separating mixtures by giving them supplementary materials like worksheets. However, their scores are still low. I was very eager to push through this study so that I could help my learners improve their academic performance and at the same time provide them the best learning experience in honing their maximum and optimum potentials, hence this action research is imperative.

\section{Statement of the Problem}

The central focus in conducting this action research was to find out how the academic performance of my learners on the topic of separating mixtures was made better.

Specifically, my study was designed to answer the following: 
1. Can Strategic Intervention Material (SIM) crafted by the researcher focusing on decantation and evaporation as processes of separating mixtures affect the learners' academic performance on the topic of separating mixtures?

2. How Strategic Intervention Material (SIM) improve learners' performance on the topic of separating mixtures particularly on decantation and evaporation?

3. What are the challenges and successes experienced during the distribution, administration, and retrieval of the Strategic Intervention Material (SIM) from the learners since there is no face-to-face interaction allowed to happen?

\section{THEORETICAL FOUNDATIONS}

My research focused on improving the academic performance of my learners on the topic of separating mixtures specifically on decantation and evaporation using strategic intervention material. The said material is an instructional tool used for remediating learners with poor academic performance. (Department of Education, 2005) entitled "Training Workshop on Strategic Intervention Materials (SIMs) for Successful Learning" offered teachers the opportunity to be trained in developing the said learning intervention. During science fairs held in schools up to national levels, Strategic Intervention Material (SIM) making was then included up to this time.

Moreover, the Continuous Improvement Team of Rizal Central Elementary School, which I am fortunately part of as the team's process observer, has conceived a process in developing Strategic Intervention Material (SIM) named Project 3Ds: Discover, Design, and Deliver a Process on Developing Strategic Intervention Materials in Science. The process was already proven effective and efficient since it has already undergone pilot testing and was implemented through a three-day training in Rizal Central Elementary School last 2020.

\section{METHODOLOGICAL PROCEDURES}

This chapter presents the research design, respondents and sampling method, research instrument, data gathering procedures, data analysis, and ethical considerations of the study.

\subsection{Research Design}

For this study, I utilized action research as a type of qualitative research to solve a classroom-based problem.

\subsection{Respondents and Sampling}

Rizal Central Elementary School is the only central school in Barangay Kapatagan. The enrollment of the school varied from year to year. Some of the learners do enroll in urban schools while some transfer from one school to another within the barangay due to the accessibility of the school and the livelihood of their parents which are commonly situated near the location of the school. The number of enrolled learners in my science class was 44 learners, comprising 26 boys and 18 girls. For this study, only ten (10) identified participants have gone through the intervention. These participants are found to have the lowest scores obtained from the pretest administered to them on the fifth week of the first grading period school year 2020-2021. The results of their pretest and the word of mouth from their previous Science teachers in grade 5 became the bases for them to be included in the intervention program. The learning material for the intervention program comprised guide cards, activity cards, assessment cards, enrichment cards and reference card. Each card was carefully crafted and validated by Master Teachers and the Education Program Supervisor 
in Science prior to it is use in the field. Thus, its content was well anchored to the sub-tasked competency or focus skills being developed.

\subsection{Research Instrument}

The learners' thoughts and perspectives on the use of SIM were collected through a Perception Survey Questionnaire (PSQ) that was modified from the study conducted by (Salviejo, Aranes, \& Espinosa, 2014). The survey comprised of ten (10) questions validated by group of master teachers and the school principal of Rizal Central Elementary School. The material was prepared in the form of a checklist using 1-4 scales with the following qualitative description: 1strongly disagree, 2- disagree, 3-agree, and 4-strongly agree. It was also utilized as a tool to gather the challenges and successes experienced during the distribution, administration, and retrieval of the Strategic Intervention Material (SIM) from the learners.

\subsection{Data Gathering Procedure}

The first step done for this study was the discussion of the problem to the class adviser by the researcher. The exchange of thoughts and ideas on the discussion made were documented and jotted in my journal.

The second step was the administration of the pretest to learners on the topic of separating mixtures specifically decantation and evaporation. The test given to the participants of the study comprised a total of 10 questions that were validated by group of master teachers and the Education Program Supervisor for Science. The questions of the tests are assessed through Fairness of Items Tool (FIT) by (Hicks, 2012). Revisions on the tool were made to fit for my study. The test that was answered by the participants was returned to me after a week that it was distributed. The retrieval of the test took it so long because of the rules and regulations of the school that should be followed in times of health crisis. The results of the test were recorded as these are very useful in analyzing the data for this study.

The third step was the discussion of the problem to parents or guardians of the identified learners through an orientation held at Grade Six section Bonifacio classroom. The orientation was called forth at exactly 8:00 o'clock in the morning. Before the orientation had begun, attendance sheet was signed by the parents. During the orientation, the parents were informed on the pretest results of their child and conduct of the intervention program to improve their academic performance. The anatomy of the strategic intervention material crafted by the researcher was shown and explained to the attendees. They were also informed on the schedules prepared by the researcher as presented in the Table 1 below.

Table 1. Schedule in answering the Strategic Intervention Material (SIM), retrieval of the Strategic Intervention Material (SIM), administration, retrieval of the posttest material, and perception questionnaire survey

Activities

For Decantation

Answering of Activity Card 1

Answering of Activity Card 2

Answering of Activity Card 3

Answering of Assessment Card 1

Answering of Assessment Card 2

Answering of Enrichment Card

For Evaporation

Answering of Activity Card 1A

Answering of Activity Card 1B
Week to be answered

$3^{\text {rd }}$ week of December 2020

$3^{\text {rd }}$ week of December 2020

$4^{\text {th }}$ week of December 2020

$4^{\text {th }}$ week of December 2020

2nd week of January 2021

2nd week of January 2021

3rd week of January 2021

3rd week of January 2021 
Answering of Activity Card 2 Answering of Activity Card 3 Answering of Assessment Card Answering of Enrichment Card Answering of Retrieval of Strategic Intervention Material (SIM)

Administration and Retrieval of Post Test Perception Questionnaire Survey 4th week of January 2021

4th week of January 2021

5 th week of January 2021

5 th week of January 2021

January 28, 2021

January 29, 2021

January 30,2021

The Strategic Intervention Material (SIM) that I gave was intended to be answered for six weeks which began on the $3^{\text {rd }}$ week of December and ended on the last week of January 2021.It was scheduled this way because the different cards of the Strategic Intervention Material (SIM) were designed to be answered for six weeks from the Activity Cards down to the Enrichment Cards.

The fourth step was the utilization of the crafted Strategic Intervention Material (SIM) of the researcher on the topic of separating mixtures focusing on decantation and evaporation. Each participant was handed a copy of the material wherein each one was able to perform the tasks on separating mixtures and answered the questions incorporated in the cards. The Strategic Intervention Material (SIM) composed of lessons on decantation and evaporation was provided with guide cards, activity cards, assessment cards, enrichment cards and reference card. At home, learners were guided on when to answer the cards regardless of the time of the day that they would answer since their parents were informed of the schedule on when cards will be answered or performed. Schedules on answering the material were followed based on the texts, calls and chats in messenger given by the parents when followed up on how well the participants went through the given material.

On the day when the Strategic Intervention Material (SIM) was retrieved, the posttest material was distributed to parents. They were instructed to let their learners answer the test and submit it on the following day. Lastly, the learners' thoughts and perspectives on the use of SIM were collected through a Perception Survey Questionnaire (PSQ) that was modified from the study conducted by (Salviejo, Aranes, \& Espinosa, 2014). The survey comprised of ten (10) questions validated by group of master teachers and the school principal of Rizal Central Elementary School. The material was prepared in the form of a checklist using 1-4 scales with the following qualitative description: 1-strongly disagree, 2- disagree, 3-agree, and 4-strongly agree. It was also utilized as a tool to gather the challenges and successes experienced during the distribution, administration, and retrieval of the Strategic Intervention Material (SIM) from the learners.

\subsection{Data Analysis}

For analysis and interpretation of the data, the statistical treatment that was used in the study was paired t-test to show the significant difference between pre-test and posttest as to show the impact of Strategic Intervention Material (SIM) after being administered to the learners. I also analyzed the result of the Perception Survey Questionnaire (PSQ) and computed its weighted mean score by adding the product of the number of responses in each scale and divided by the number of respondents. Overall weighted mean was also computed by adding the weighted mean score and divided it by ten since there are ten statements comprising the questionnaire. The survey made use of scales 1-4 with corresponding qualitative description such as 1-strongly disagree, 2- disagree, 3agree, and 4-strongly agree. Qualitative descriptions were based on the weighted mean computed using the ranges: 1-1.49 strongly disagree; 1.5-2.49 disagree; 2.5-3.49 agree; and 3.5-4.0 strongly agree. These important data were collected and served as foundation to find out the how Strategic Intervention Material (SIM) improved the academic performance of the Grade Six Bonifacio learners.

\subsection{Ethical Considerations}


As a researcher, the well-being of the participants was one of the main concerns to be put into consideration.

Prior to the discussion of the problem to the parents, permission letters were secured from the principal as well as the participants. The purpose of my study was intensively shared to them so that they well be able to understand my cause.

Even if my action research is purely academic, I gave them an informed consent form and allowed them to read the agreement stating the main purpose and rationale of my action research. According to Bailey (1996), an informed consent agreement includes the following: that they are participating in research, they know the purpose of the research, the procedures of the research, the risk benefits of the research, the voluntary nature of research participation, the participants, or informants right to stop the research at any time, and the procedures used to protect confidentiality.

To assure privacy and confidentiality of the information that the study participants had shared, they are informed that they are free to withhold their names or use any pseudonym of their choice. Conflict of interest was addressed through constant phone calls and chats. The information derived based on the activity were written in my journal. The journal was used as a monitoring tool which gave me a clear glimpse that the learners have really done their tasks at home well.

\section{RESULTS AND DISCUSSION}

This chapter deals with the presentation, analysis and interpretation of the data gathered from the pretest and post test administered to the learners and the effect of the strategic intervention material as an intervention for remediation, the result of the perception questionnaire survey and my reflection on the challenges and successes experienced during the distribution, administration, and retrieval of the Strategic Intervention Material (SIM).

\section{The Result of Using the crafted Strategic Intervention Material-Go and Separate}

Going back to the research question no. 1 which was, "Can Strategic Intervention Material (SIM) crafted by the researcher focusing on decantation and evaporation as processes of separating mixtures affect the learners' academic performance on the topic of separating mixtures?", definitely the answer was, "yes." It can be glimpsed on Figure 1 below the evidence on the effectiveness of the crafted Strategic Intervention Material (SIM) for Grade VI-Bonifacio learners.

Figure 1. The mean scores of the pretest and post test conducted to the learners

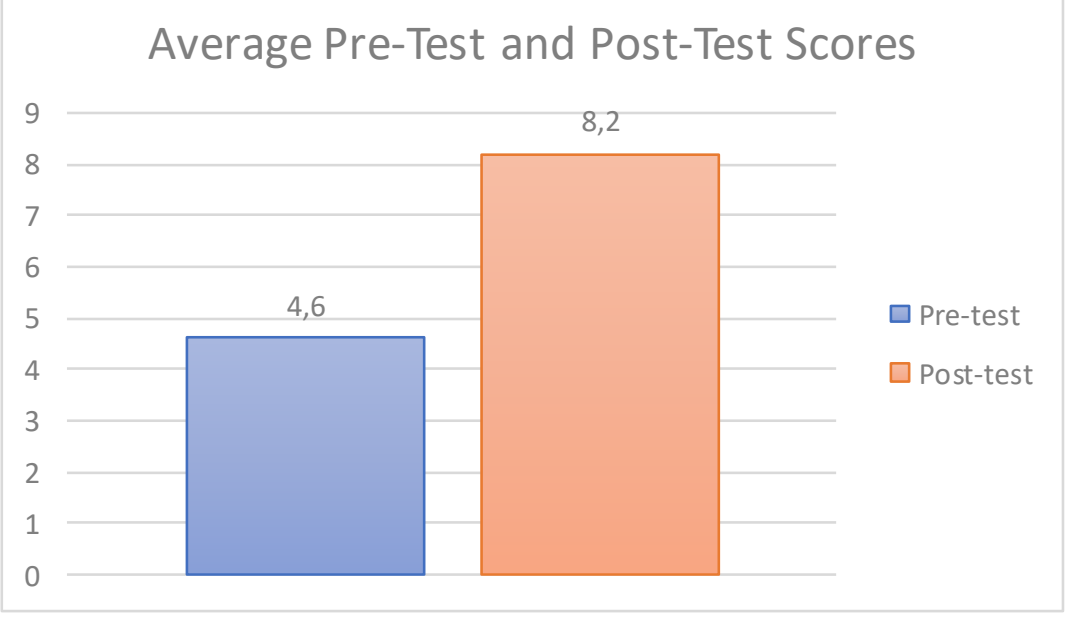


The mean score of the pretest conducted was 4.6 points. While the post test was 8.2 points after the Strategic Intervention Material (SIM) was given and answered by the participants.

Table 2. Paired Sample T-Test

\begin{tabular}{|c|c|c|c|c|c|}
\hline & & & statistic & df & $\mathrm{p}$ \\
\hline Pretest & Posttest & Learner's t & -5.373 & 9 & .000 \\
\hline
\end{tabular}

Table 3. Descriptive Statistics for Pretest and Posttest

\begin{tabular}{lllll}
\hline & Mean & $\mathrm{N}$ & Std. Deviation & Std. Error Mean \\
\hline Pretest & 4.60 & 10 & 1.713 & .542 \\
Posttest & 8.20 & 10 & .919 & .291 \\
\hline
\end{tabular}

This study was conducted to determine if there are changes on the pretest and posttest scores of the learners after the administration of Strategic Intervention Material (SIM) to the participants through a paired samples t-test.

Results revealed that there was a significant difference between the $\operatorname{pretest}(M=4.60$. $s=1.713)$ and posttest $(M=8.20, s=.919), t(9)=-5.373, p=.000$. With these results, the crafted intervention material has improved the academic performance of my learners' needing remediation. In line with the perspective of (Dahar, 2011), a literacy-enriched environment with various instructional materials impacts the academic performance of the learners. These materials play an indispensable role in the teaching-learning phase. Further, (Escoreal, 2012) cited that Strategic Intervention Material (SIM) provided a point of reference and should be used in school to avoid labelling of the learners under marginalization. A strategically designed intervention material was an effective tool in mastering a least-learned competency.

\section{Learners' Perception on the Use of the Strategic Intervention Material}

The thoughts and perspective of the learners on the use of strategic intervention material have been collected through the perception survey questionnaire (PSQ). The survey comprised 10 statements about the use of the strategic intervention material. Scales 1-4 were used with corresponding qualitative description such as 1-strongly disagree, 2- disagree, 3-agree, and 4strongly agree. Qualitative descriptions were based on the weighted mean computed using the ranges: 1-1.49 strongly disagree; 1.5-2.49 disagree; 2.5-3.49 agree; and 3.5-4.0 strongly agree. The data gathered are presented in Table 3 below.

Table 3. Learners' Perception on the Use of Strategic Intervention Material (SIM)

\begin{tabular}{|c|c|c|c|c|c|c|}
\hline \multirow[t]{2}{*}{ Statements } & \multicolumn{4}{|c|}{ Rating } & $\begin{array}{l}\text { W. } \\
\text { Mean }\end{array}$ & $\begin{array}{l}\text { Qualitative } \\
\text { Description }\end{array}$ \\
\hline & 1 & 2 & 3 & 4 & & \\
\hline \multicolumn{7}{|c|}{ Frequency } \\
\hline $\begin{array}{l}\text { 1. The SIM helped me understand how separating mixtures } \\
\text { through decantation and evaporation were done. }\end{array}$ & 0 & 1 & 3 & 6 & 3.5 & SA \\
\hline $\begin{array}{l}\text { 2. The way on how the concepts of the SIM was clearly presented } \\
\text { and appropriate to my needs. }\end{array}$ & 0 & 1 & 2 & 7 & 3.6 & SA \\
\hline $\begin{array}{l}\text { 3. I could easily comprehend the explanations provided by the } \\
\text { SIM. }\end{array}$ & 0 & 0 & 2 & 8 & 3.8 & SA \\
\hline $\begin{array}{l}\text { 4. I learned some useful information not mentioned in the } \\
\text { worksheet after using the SIM. }\end{array}$ & 0 & 1 & 4 & 5 & 3.4 & A \\
\hline 5. The cards allotted were adequate for each lesson. & 0 & 1 & 3 & 6 & 3.5 & SA \\
\hline
\end{tabular}


6. Activities and tasks incorporated in the SIM were very easy.

$\begin{array}{lllll}0 & 1 & 1 & 8 & 3.7\end{array}$$$
3.7
$$
the SIM.

8. SIM made use of the words and terms which are suited to my reading comprehension.

9. SIM inspired and encouraged me to learn more topics in separating mixtures.

10. I am eager to use SIM in a the digital-modular modality of learning next time.
SA

SA

SA

SA

SA

Presented above were the responses of the participants on the perception survey questionnaire given to them. The frequency of responses by the participants varied from each other. Further, it can be observed that the identified learners who have undergone the strategic intervention material entitled "Go and Separate" displayed a great interest in using Strategic Intervention Material (SIM) as one of the materials to be given by the teacher in digital-modular modality of learning. Statement number 10 ranked number 1 after yielding a rating of 3.9.

Statement number 3, "I could easily understand the explanations provided by the SIM" ranked number 2 with the rating of 3.8. The Strategic Intervention Material (SIM) crafted by the researcher provided explanations on the topics on decantation and evaporation. Explanation of concepts are necessary in understanding lessons in science.

Following are statements number 6,7 , and 9 with a yielded rating of 3.7 . Required tasks incorporated in the Strategic Intervention Material (SIM) were very easy. During the orientation, I really informed the parents that the Strategic Intervention Material (SIM) that I made was not meant to punish their child. It was meant to help them master the competencies that were difficult for them to understand. I also encouraged them to let their child explore its contents. When I asked the parents during the retrieval of the SIM distributed to them, they said that their child enjoyed reading and doing all activities. It gave them inspiration and enthusiasm to learn more topics in separating mixtures.

Statement number 2 and 8 yielded a rating of 3.6. The presentation of the concepts in the Strategic Intervention Material (SIM) was clear and appropriate to the needs of the participants. Illustrations on the concepts explaining how decantation and evaporation were done are well presented on the two guide cards in the Strategic Intervention Material (SIM). The Strategic Intervention Material (SIM) used words and terms suited to their reading comprehension because during its validation, words which are difficult to comprehend are simplified to avoid language barrier.

Next in rank were statements number 1 "the SIM helped me understand how separating mixtures through decantation and evaporation were done" and number 5 "the cards allotted were adequate for each lesson." It garnered a rating of 3.5. Participants found SIM helpful in understanding how separating mixtures through decantation and evaporation were done and appreciated that the number of cards allotted were adequate for the development of lessons on decantation and evaporation. The guide cards of the crafted Strategic Intervention Material (SIM) gave the overview of the two separating techniques. Words which are difficult to understand were also given definition. Activity cards helped them master the concepts, assessment cards assessed their understanding and lastly enrichment cards are given to apply what they have learned from the previous cards that they have answered. A reference card was also provided for them to have further reading on the two concepts of separating mixtures. All of these allowed the participants to understand how the two separation techniques: decantation and evaporation worked.

Statement number 4 "I learned some useful information not mentioned in the worksheet after using the SIM" ranked last with a rating of 3.4 interpreted as agree. The information presented in the Strategic Intervention Material (SIM) are useful as they thoroughly explained how the two separation techniques be made. When I asked the participants on how well the information are presented in the Strategic Intervention Material (SIM) compared on the worksheet that I also gave 
to them, they shared that it was well expounded in the latter rather than the previous one. I told them that two learning materials have the same nature which was to help learners understand concepts and ideas. However Strategic Intervention Materials (SIMs) are developed with the sole purpose of helping learners cope up or master a least-learned competency while worksheets are created to measure learners' understanding on a certain topic.

Lastly, the overall weighted mean was 3.64 with the equivalent qualitative description of strongly agree. It indicated how Strategic Intervention Material (SIM) improved learners' performance on the topic of separating mixtures particularly on decantation and evaporation.

The use of Strategic Intervention Material (SIM) has improved the academic performance of the learners because through this material, they were able to understand and familiarize the difficult concepts in separating mixtures such as decantation and evaporation. The material was embodied with various cards which were designed to be understood and performed by the learners independently.

\section{Challenges and successes experienced during the distribution, administration, and retrieval of the Strategic Intervention Material}

At this time of global pandemic, $100 \%$ of the learners are at home and opt for blended modality, and how are they going to cope with the global education obligation is a big challenge. In Digos City Division, both elementary and secondary schools embarked on the development of the Basic Education-Learning Continuity Plan (BE-LCP) to enable learners of basic education to continue learning, and for teachers to be able to deliver instruction in a safe work and learning environment amid the threat of COVID-19 (DepEd, 2020).

The task of making learners improve academic performance has become even more challenging with the advent of COVID-19 pandemic which causes tremendous change in the country's education system. Just in a matter of months, the pandemic has affected the daily routines of the learners and the teaching-learning process itself resulting in closure of schools and restrictions of movements (Tidey, 2020).

Moreover, COVID-19 pandemic has challenged the Department of Education most especially the teachers who has a very vital role in assuring that education will still be served to all the learners in the community. Schools have been affected because classes which are done through face-to-face interaction were stopped because learners are of great risk of getting infected by the disease. During one of the meetings conducted in our school, the parents and stakeholders of Rizal Central Elementary School have chosen blending learning specifically digital-modular learning modality because this was the only modality that would reach the learners in our community.

Most of our learners belong to less-fortunate families who are apparently not capable of providing the necessary tools and equipment like computer, smartphones, internet connections, television, etc. for them to participate in online learning and other learning modalities. Many of them also reside in far-flung areas where signal reception is not possible so the above stated modality best fit for them.

Worksheets, radio-based instructions, and television-based instructions put in a flash drive were placed in a learning kit and were distributed to the learners through their parents. In our school, schedules of distribution of the learning kit were communicated to the parents to maintain social distancing. When the SIM was distributed, coordination with the class adviser was made. When they brought the SIM home, their kids had a lot of fun and they said that they enjoyed answering the material. I have created a group chat in messenger for me to connect with my learners. Calls and texts were also made especially when there are things that they find difficult in the material. As their Science teacher, I felt so overwhelmed when I reached to them and vice versa. It was an experience full of fun to teach the concepts over the phone to your learners at nighttime or daytime. So, the pandemic never stopped us to learn concepts in Science. 
During the retrieval of material, the parents shared that they were glad to become part of the intervention program. I also shared to them what their children have done like calling, texting, and chatting me when something bothered them while answering the material.

It is highly recommended that science teachers can use Strategic Intervention Material (SIM) to re-teach the concepts and skills and help the pupils master the competency-based skill (Suarez \& Leomarich, 2020). Strategic Intervention Material (SIM) was made with a goal in mind which is to be answered by the learners even in the absence of the teacher or adult companion at home.

\section{CONCLUSION}

\section{Implication to Education}

The entirety of this action research has provided me essential and useful data which will serve as an eye opener in the field to give importance to the essence of crafting Strategic Intervention Material (SIM) as a tool for remediation.

\section{Implication for Policy Making and Practice}

This study provides relevant and essential information for the school to provide effective intervention to learners with difficulty in mastering a competency and will become a basis in crafting policy to be applied in the school level. The Continuous Improvement Project in our chool entitled Project 3Ds (Discover,Design and Deliver): A Process on Developing Strategic Intervention Material (SIM) can also be tapped to conduct trainings to streghten the crating of Strategic Intervention Material (SIM).

For future researchers, it is also important that a study will also be conducted to help them eliminate the learning gaps of other disciplines like English and Mathematics since there are also learners who have difficulties on these core subjects.

\section{REFERENCES}

American Psychological Association. (2010). Publication Manual of the American Psychological Association (6 ed.). Washington, DC, USA: American Psychological Association.

Bailey, E. 2012. Instructional Pedagogies in the Modern Classroom. Chicago Publishing House, Chicago, USA.

Dahar, M. (2011). Effect of the Availability and the Use of Instructional Material on Academic Performance of Students. Punjab (Pakistan): Euro Journal Publishing Inc.

Department of Education. (2020). Learning Opportunities Shall be Available The Basic Education Learning Continuity Plan in the Time of COVID-19. https://www.deped.gov.ph/wpcontent/uploads/2020/07/DepEd_LCP_July3.pdf

Department of Education. (2005). Training Workshop on Strategic Intervention Materials (SIMs) for Successful Learning. DepEd Memo No. 117.

Escoreal, A. (2012). Strategic Intervention Material A Tool to Reduce Least Learned Skills in Grade Four Science.

Hicks, N. A. (2012). Fairness of Items Tool (FIT).

McNiff, J., \& Whitehead, J. (2006). All You Need to Know About Action Research An Introduction. London, UK: SAGE Publications, Ltd.

Salviejo, E. I., Aranes, F. Q., \& Espinosa, A. A. (2014). Strategic Intervention Material-Based-Instruction, Learning . Manila, Philippines.

Suarez, Michael \& Casinillo, Leomarich. (2020). Effect of Strategic Intervention Material (SIM) on Academic Performance: Evidence from Students of Science VI. 4. 20-32.

Tidey, C. (2020). COVID-19: Children at heightened risk of abuse, neglect, exploitation and violence amidst intensifying containment measures. UNICEF. https://www.unicef.org/press-releases/unicef-issues-record-us64billion-emergency-funding-appeal-reach-more-190-million 